\title{
Evaluation of Physico-Chemical Characteristics of Certain Fish Ponds of B. U. Bhopal
}

\author{
Santosh Kumar ${ }^{1}$, Shriparna Saxena ${ }^{2}$ \\ Department of Zoology and Applied Aquaculture Barkatullah University Bhopal 462026 India
}

\begin{abstract}
This research article deals with the study of quality of pond water. Pond water samples were collected from 4 Ponds in Bu Bhopal. Samples were analyzed for physico-chemical parameters including $\mathrm{pH}$, total dissolved solids (TDS), temperature, and salinity and dissolved oxygen $(\mathrm{DO})$. pH ranged from 6.50 - 9.69, TDS ranged from $165.5-254.8 \mathrm{ppm}$, Temperature ranged from $20.9-33.8^{\circ} \mathrm{C}$, Salinity ranged from $5.1-6.9 \mathrm{ppt}$, Dissolved oxygen ranged from $2.41-4.8 \mathrm{mg} / \mathrm{l}$. Correlation coefficient (r) was found significant at $p<0.05$ level for the tasted parameters. The result of the proposed study will establish some facts about the use of water for various purposes like domestic and agriculture.
\end{abstract}

Keywords: water, fish, $\mathrm{pH}$, pond

\section{Introduction}

Aquaculture can be defined as the high-density production of fish, shellfish and plant forms in a controlled environment. Stocking rates for high-density aquaculture are typically thousand fold greater than wild environments. These principles compose the subject of water chemistry and its net result i.e. the water quality. Poor water chemistry leads to deteriorate water quality, which causes stress to the organisms being raised. Efficient feed conversion, growth and marketability of the final product cannot occur unless the pond system is balanced or in harmony with nature. Therefore the overriding concern of the fish culturist is to maintain, 'balance' or 'equilibrium conditions' with respect to water chemistry and its natural consequence, good water quality. Water quality is the summation of all physical, chemical, biological, and aesthetic characteristics of water that influence its beneficial use.

\section{Material and Method}

\section{Study site characteristics}

The study site of Barkatullah University Bhopal on the campus certain pond of department of zoology and applied aquaculture. The study area and pond are total no. 14 and the measurement of the some ponds of the phycio- chemical parameters on the BOD, Do, COD, Water quality Hardness and $\mathrm{pH}$, alkanity, Temperature and other parameters measurement of the different equipment use and different methods are use to this experiment.

\section{Water Sampling Procedure and Analysis}

The water samples were analyzed for various parameters in the laboratory of Department. Various physical and chemical parameters like Temperature, $\mathrm{pH}$, Turbidity, Total Dissolved Solids (TDS), Total Suspended Solids (TSS), Hardness, Biochemical Oxygen Demand (BOD), Dissolved Oxygen (DO), Residual Chlorine, Chloride, Alkalinity have been monitored for the tap water of different locations. Plastic bottles of 1.5 liter capacity with stopper were used for collecting samples. Each bottle was washed with $2 \%$ Nitric acid and then rinsed three times with distilled water. The bottles were then preserved in a clean place. The bottles were filled leaving no air space, and then the bottle was sealed to prevent any leakage.

\section{Results}

Water quality parameters for aquaculture ponds

\begin{tabular}{|c|c|c|c|c|c|}
\hline Sr.No & Water parameter & Pond 1 & Pond 2 & Pond 3 & Pond 4 \\
\hline 1. & Temperature & $26-33{ }^{\circ} \mathrm{C}$ & $26-30{ }^{\circ} \mathrm{C}$ & $25-32^{\circ} \mathrm{C}$ & $26-34^{\circ} \mathrm{C}$ \\
\hline 2. & Salinity & $10-25 \mathrm{ppt}$ & $10-16 \mathrm{ppt}$ & $10-21 \mathrm{ppt}$ & $10-24 \mathrm{ppt}$ \\
\hline 3. & Dissolved oxygen & $>3.0 \mathrm{ppm}$ & $>3.05 \mathrm{ppm}$ & $>4.5 \mathrm{ppm}$ & $>5.05 \mathrm{ppm}$ \\
\hline 4. & $\mathrm{pH}$ & $7.5-8.5$ & $7.5-8.9$ & $7.5-8.4$ & $7.5-8.3$ \\
\hline 5. & Total Ammonia Nitrogen & $<1.0 \mathrm{ppm}$ & $<1.03 \mathrm{ppm}$ & $<1.02 \mathrm{ppm}$ & $<1.03 \mathrm{ppm}$ \\
\hline 6. & Total Nitrate Nitrogen & $<5.0 \mathrm{ppm}$ & $<5.02 \mathrm{ppm}$ & $<5.01 \mathrm{ppm}$ & $<5.03 \mathrm{ppm}$ \\
\hline 7. & Nitrite Nitrogen & $<0.01 \mathrm{ppm}$ & $<0.012 \mathrm{ppm}$ & $<0.01 \mathrm{ppm}$ & $<0.01 \mathrm{ppm}$ \\
\hline 8. & Sulphide & $<0.03 \mathrm{ppm}$ & $<0.032 \mathrm{ppm}$ & $<0.03 \mathrm{ppm}$ & $<0.03 \mathrm{ppm}$ \\
\hline 9. & BOD & $<10 \mathrm{ppm}$ & $<12 \mathrm{ppm}$ & $<11 \mathrm{ppm}$ & $<10 \mathrm{ppm}$ \\
\hline 10. & COD & $<70 \mathrm{ppm}$ & $<73 \mathrm{ppm}$ & $<72 \mathrm{ppm}$ & $<75 \mathrm{ppm}$ \\
\hline 11. & Sacchi disc visibility & $25-45 \mathrm{~cm}$ & $25-48 \mathrm{~cm}$ & $25-55 \mathrm{~cm}$ & $25-50 \mathrm{~cm}$ \\
\hline
\end{tabular}

\section{Conclusion}

This study observed that fish ponds in the investigated areas used slightly alkline water for fish production while ammonia, BOD levels were fairly high. The high content of BOD will deplete the DO amount which will eventually be harmful to aquatic life. Lime application will correct $\mathrm{pH}$ to a more acceptable level for fertilizer use. There is also the desirable need to analyze the pond water at regular intervals. This will ensure that some of the parameters in this study will not exceed levels that could be harmful to fish in the environment. Such a measure will guarantee the safety of the

\section{Volume 6 Issue 12, December 2017}




\section{International Journal of Science and Research (IJSR) \\ ISSN (Online): 2319-7064}

Index Copernicus Value (2016): 79.57 | Impact Factor (2015): 6.391

aquatic ecosystem, humans and environment for good and healthy production of fish for consumption

\section{Suggestion}

The following guidelines are given to a fish farmer to know when pond water is deteriorating in quality and therefore not suitable for fish growth.

1) Clear water indicates very low or absence of biological production- not fertile enough and fish will not grow well in it.

2) Muddy water (that is a lot of clay particles are present), fish can have their gills blocked by the soil particles and this can result in death - not good for fish culture.

3) Deep green water indicates over-production of planktons that serve as food for fish but occur as a result of application of more than enough fertilizers, manure or nutrient rich feeds to a pond.

4) When a fish pond gives an offensive odor, it indicates pollution of pond water. Sources of pollution include application of excess food stuff to the pond, or inflow of water from polluted rivers. Pollution can also result from application of chemicals to arable crops around the pond site.

\section{References}

[1] Ekubo, A. A. and Abowei, J. F. N., (2011), Review of some water quality management principles in culture fisheries, Research Journal of Applied Sciences, Engineering and Technology, 3(2), pp 1342-1357.

[2] Abowei, J. F. N., (2010), Salinity, Dissolved Oxygen, pH and surface water temperature conditions in Nkoro River, Niger Delta, Nigeria, Advance journal of food science and technology, 2(1), pp 16-21.

[3] Sikoki, F.D. and J.V. Veen, (2004), Aspects of Water Quality and the Potential for Fish Production of Shiroro Reservoir Nigeria, Living System Sustainable development, 2, pp 7.

[4] Meck Norm., (1996), Pond water chemistry, San Diego, Koi

Club,

Http://users.vcnet.com/rrenshaw/h2oquality.html

Revised on July 31, 1996.

[5] Kiran, B. R., (2010), Physico-chemical characteristics of fish ponds of Bhadra project at Karnataka, RASĀYAN Journal of Chemistry, 3(4), pp 671-676.

Volume 6 Issue 12, December 2017 